\title{
Fibroblast Growth Factor 14
}

National Cancer Institute

\section{Source}

National Cancer Institute. Fibroblast Growth Factor 14. NCI Thesaurus. Code C147995.

Fibroblast growth factor 14 (247 aa, $28 \mathrm{kDa}$ ) is encoded by the human FGF14 gene.

This protein is involved in signal transduction in central nervous system development. 